\title{
Banded karyotypes of the Northern pike, Esox lucius (Esocidae) in Turkey
}

\author{
Atilla ARSLAN ${ }^{1 * D}$, Zafer ALPASLAN ${ }^{2}$ iD \\ ${ }^{1}$ Department of Biology, Faculty of Science, Selçuk University, Konya, Turkey \\ ${ }^{2}$ Graduate School of Natural Applied Sciences, Selçuk University, Konya, Turkey \\ *Corresponding Author: aarslan@selcuk.edu.tr
}

Research Article

Received 07 May 2020; Accepted 02 July 2020; Release date 01 December 2020.

How to Cite: Arslan, A., \& Alpaslan, Z. (2020). Banded karyotypes of the Northern pike, Esox lucius (Esocidae) in Turkey. Acta Aquatica Turcica, 16(4), 511-515. https://doi.org/10.22392/actaquatr.733738

\begin{abstract}
In this study, cytogenetic properties of E. lucius in Sakarya River were investigated using standard Giemsa staining, Cand Ag-NOR banding techniques. The number of diploid chromosomes ( $2 \mathrm{n}$ ) of individuals studied is 50 and karyotype consists of 50 acrocentric chromosomes with decreasing sizes. Secondary constriction was observed on the third autosomal pair in the karyotype. Morphologically distinguishable sex chromosomes were not detected in male and female individuals. Some chromosomes were centromeric C-positive, while some chromosomes were negative. Active NOR is localized in the pericentromeric region of the third autosomal pair and it is related to C-heterochromatin. Our results are similar to those of other studies and this result shows that the cytogenetic properties of the species are quite stable. Moreover, these results may contribute to the cytogenetic and phylogenetic studies of the Esox species in the future.
\end{abstract}

Keywords: Chromosome, Ag-NOR band, C-band, northern pike, Turkey

Türkiye'deki Turna Balığı, Esox lucius (Esocidae)'un Bantlı Karyotipleri

Özet

Bu çalışmada, Sakarya Nehri'ndeki E. lucius'un geleneksel Giemsa boyama, C- ve Ag-NOR bantlama teknikleri kullanılarak sitogenetik özellikleri araştırıldı. Çalışılan bireylerin diploid kromozom sayısı (2n) 50'dir ve karyotip azalan büyülükte 50 akrosentrik kromozomdan oluşmaktadır. Karyotipte, üçüncü otozomal çiftte ikincil boğum gözlemlendi. Erkek ve dişi bireylerde morfolojik olarak ayırt edilebilir cinsiyet kromozomları tespit edilmedi. Bazı kromozomlar sentromerik Cpozitif iken, bazıları negatifti. Aktif NOR'lar üçüncü otozomal çiftin perisentromerik bölgesinde lokalizedir ve Cheterokromatin ile ilişkilidir. Bulgularımız diğer çalışmaların sonuçları ile benzerdir ve bu sonuç, türün sitogenetik özelliklerinin oldukça stabil olduğunu göstermektedir, Ayrıca bu sonuçlar gelecekte Esox türlerinin sitogenetik ve filogenetik çalışmalarına katkı sağlayabilir.

Anahtar kelimeler: Kromozom, Ag-NOR bant, C-bant, turna balığı, Türkiye

\section{INTRODUCTION}

The genus Esox consists of five species distributed in North America, Europe, and Eurasia (Gandolfi et al., 2017). Northern pike Esox lucius (Linnaeus, 1758) is a broadly distributed predatory fish in the fresh waters of Eurasia and North America (Liberman et al., 2019).

Until now, the karyological properties of different populations of the genus Esox in the world have been studied (Table 1). The number of diploid chromosomes (2n) of the genus Esox in Sweden (Nygren et al., 1968), Canada (Beamis et al., 1971; Ráb and Crossman, 1994), USA (Davisson, 1972), Czechia (Ráb and Mayr, 1987; Symonová et al., 2017), Poland (Jankun et al., 1998) and China (Zou and $\mathrm{Li}, 2006)$ populations was 50.

E. lucius distributed in many freshwater ecosystems in the Black Sea and Central Anatolia in Turkey (Fricke et al., 2007). There is no study on the cytogenetic properties of Northern pike. This study aims to investigate the cytogenetic properties of Northern pike in Turkey. 
Table 1. Chromosomal records of Esox species.

\begin{tabular}{|c|c|c|c|c|c|}
\hline Species & Locality & $2 n$ & Karyotype & NF & Reference \\
\hline \multirow{9}{*}{ E. lucius } & Sweden & \multirow{19}{*}{50} & \multirow{19}{*}{$50 \mathrm{~A}$} & - & Nygren et al., 1968 \\
\hline & Canada & & & - & Beamis et al., 1971 \\
\hline & USA & & & - & Davisson, 1972 \\
\hline & Czech & & & - & Rab and Mayr, 1987 \\
\hline & Canada & & & - & Rab and Crossman, 1994 \\
\hline & Poland & & & 50 & Jankun et al., 1998 \\
\hline & China & & & 50 & Zou and Li, 2006 \\
\hline & Czechia & & & 50 & Symonová et al., 2017 \\
\hline & Turkey & & & 50 & This study \\
\hline \multirow{4}{*}{ E. americanus } & USA & & & \multirow{2}{*}{-} & Davisson, 1972 \\
\hline & Canada & & & & Rab and Crossman, 1994 \\
\hline & USA & & & & Davisson, 1972 \\
\hline & Canada & & & - & Rab and Crossman, 1994 \\
\hline \multirow{3}{*}{ E. masquinongy } & Canada & & & \multirow{3}{*}{-} & McGregor, 1970 \\
\hline & \multirow{2}{*}{ USA } & & & & Davisson, 1972 \\
\hline & & & & & Rab and Crossman, 1994 \\
\hline \multirow[t]{2}{*}{ E. niger } & \multirow[t]{2}{*}{ USA } & & & \multirow{2}{*}{-} & Davisson, 1972 \\
\hline & & & & & Rab and Crossman, 1994 \\
\hline E reicherti & USA & & & - & Davisson, 1972 \\
\hline
\end{tabular}

\section{MATERIALS and METHODS}

Three specimens of E. lucius were collected from River Sakarya $\left(39^{\circ} 20^{\prime} \mathrm{N}, 32^{\circ} 0^{\prime} \mathrm{E}\right)$, Ankara, Turkey (Figure 1). The study was undertaken and the specimens were obtained with the permission of the Republic of Turkey, Ministry of Forest and Water Works (Permit no. 21264211-288.04E.789508). The fish specimens were transported alive to the laboratory and kept in well-aerated aquaria until analysis. Chromosomes were prepared directly from the head kidney according to the method of Collares-Pereira (1992). Air-dried slides were stained conventionally by $10 \%$ Giemsa for 10 minutes. Constitutive heterochromatin and nucleolar organizer regions (NORs) were detected by the techniques of C-banding (Sumner, 1972) and Ag-NOR staining (Howell and Black, 1980), respectively. From each specimen, 10 to 20 slides were prepared, and at least 20 well-spread metaphase plates were analyzed. Definition of the shapes of the chromosomes was established according to Levan et al. (1964).

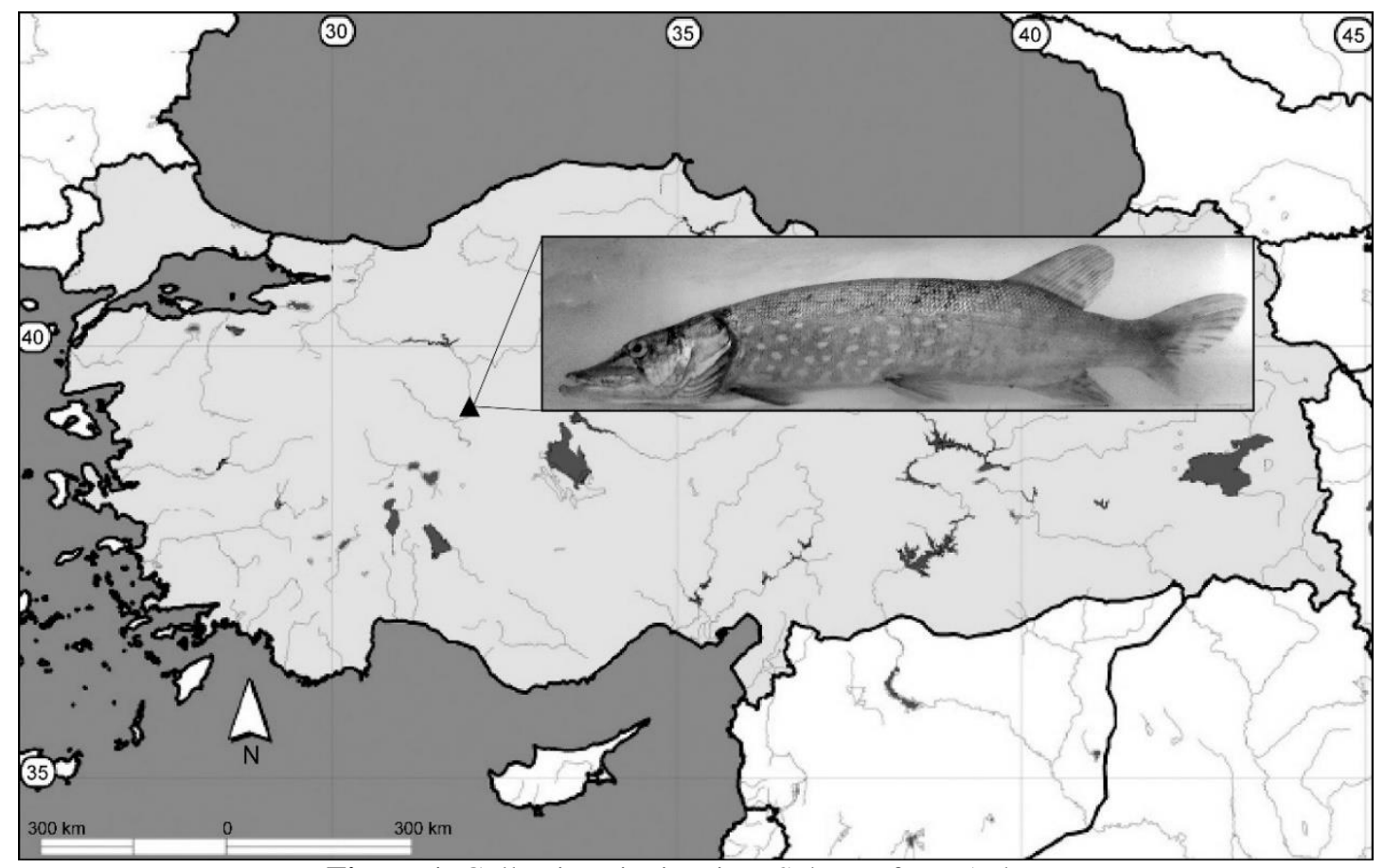

Figure 1. Collecting site in River Sakarya from Ankara. 


\section{RESULTS}

The number of diploid chromosomes (2n) of Northern pike is 50. The chromosome set consists of 50 acrocentric chromosome pairs $(\mathrm{NF}=50)$. No morphologically distinguishable sex chromosomes were detected in the set. Secondary constriction was observed in the medium-sized chromosome pair (no: 3) (Figure 2). While C-heterochromatin bands were observed in the centromeric regions of some autosomal pairs, other autosomal pairs were negative (Figure 3). Active NOR is localized in the pericentromeric region of a pair of medium-sized acrocentric chromosomes (no: 3 ) and it is related to C-heterochromatin (Figure 4).

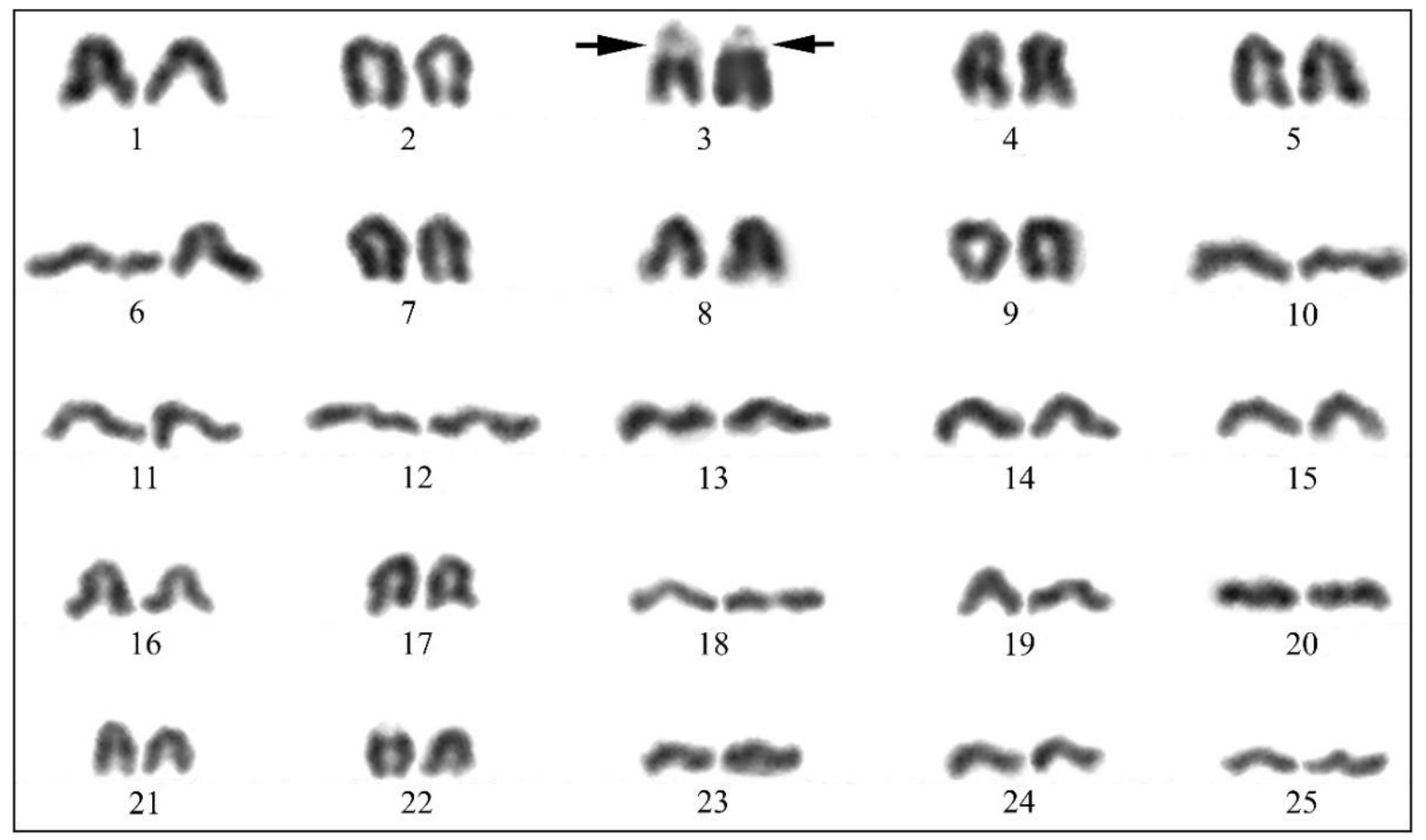

Figure 2. Standard Giemsa staining karyotype of Esox lucius. Arrows indicate the position of secondary constrictions.

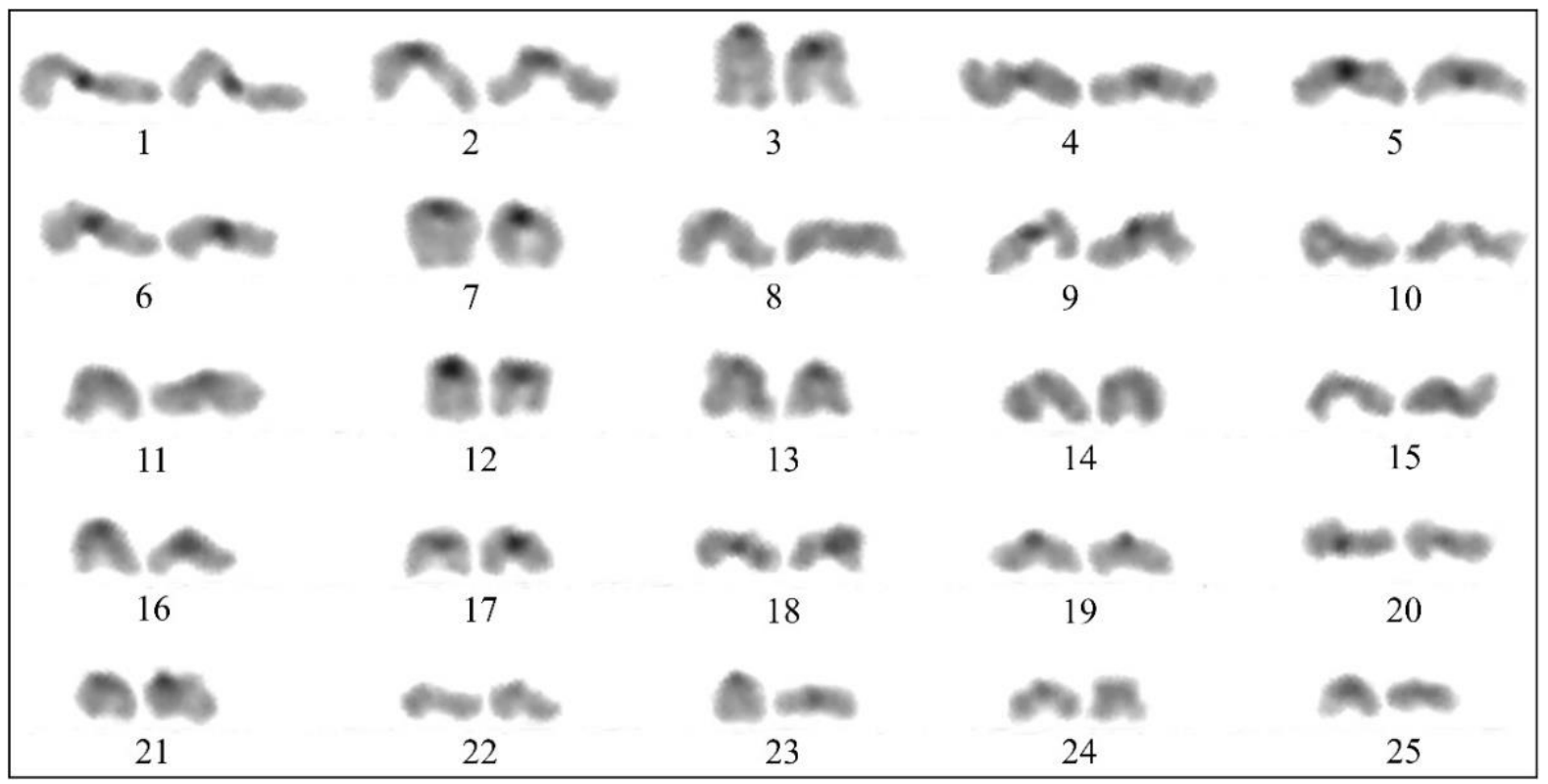

Figure 3. C-banded karyotype of Esox lucius 


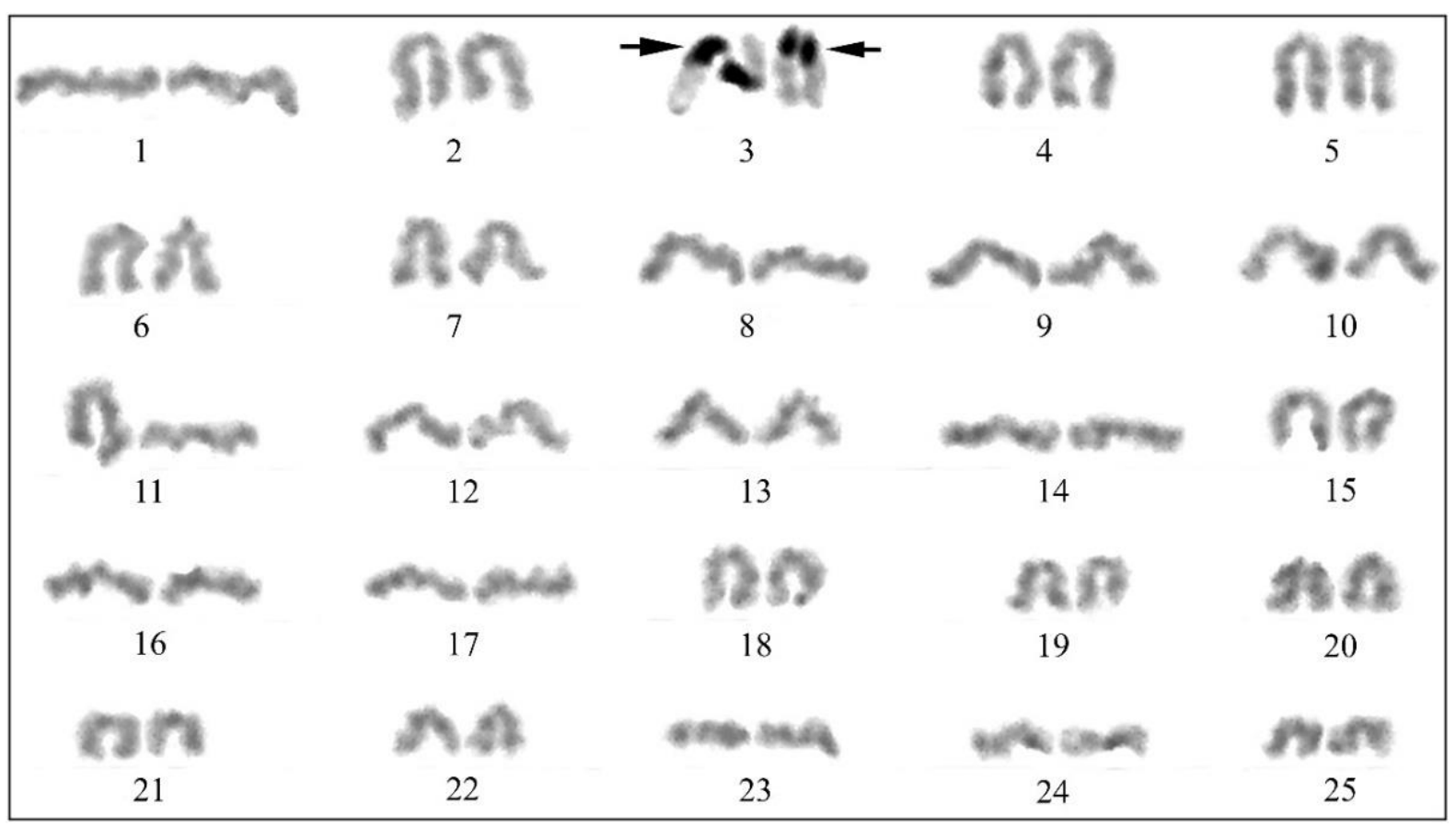

Figure 4. Silver-stained karyotype of Esox lucius. Arrows indicate the position of active Ag-NORs.

\section{DISCUSSION}

The karyological properties of E. lucius from Turkey were investigated in this study for the first time. The diploid chromosome number $(2 \mathrm{n})$ is 50 , and all the chromosomes are acrocentric. The karyological findings of E. lucius in Turkey are consistent with the results of studies in North America, Asia, and Europe (Nygren et al., 1968; McGregor, 1970; Beamis et al., 1971; Davisson, 1972; Rab and Mayr, 1987; Rab and Crossman, 1994; Jankun et al., 1998; Zou and Li, 2006; Symonová et al., 2017). Besides, a secondary constriction was identified in medium-sized chromosome pairs in both Turkey population and other populations (Rab and Mayr, 1987). In this study, sex chromosomes of E. lucius were not detected.

Heterochromatin bands contain highly repetitive DNA and are transcriptionally inactive (Sumner, 1982). The number, size, and form of the bands vary even in individuals of the same species and they are generally localized in the centromeric and telomeric regions of the chromosomes (John and Miklos, 1979). DAPI C-heterochromatin bands in E. lucius individuals from Poland are located near the centromeres of some chromosomes (Jankun et al., 1998). Turkey's population that some chromosomes have centromeric C-heterochromatin bands are compatible with the Polish population.

Locations and phenotypes of active NORs have proven useful in fish cytotaxonomy (Crossman and Rab, 2001). It has been reported in previous studies that an active NOR in the Esox and Umbra species was localized near the centromeric or pericentromeric region of the medium-sized acrocentric chromosome pair (Rab, 1981; Rab and Mayr, 1987; Rab and Crossman, 1994; Jankun et al., 1998). Rab and Crossman (1994) stated that NORs are not related to heterochromatin. However, Jankun et al. (1998) found that this NOR is related to C-heterochromatin as a result of C-banding and DAPI staining. Also the NORs is relate with heterochromatin in Turkey population. The results obtained both in this study and in other studies show that the karyotype and NORs phenotypic structure of $E$. lucius is homogeneous. Moreover, our results support the hypothesis that the NOR position of North American and European populations is shared characteristically (Rab and Crossman (1994). As a result, the karyotype properties of Northern pike with all acrocentric $(2 \mathrm{n}=50)$ chromosomes are compatible with the findings in other studies.

Acknowledgments: The standard karyological features of this study were presented as an abstract at the 1st International Symposium on Graduate Research in Science Focus on Entrepreneurship and Innovation (ISGRS 2018). 


\section{REFERENCES}

Beamish, R., Merrilees, M., \& Crossman, E. (1971). Karyotypes and DNA values for members of the suborder Esocoidei (Osteichthyes: Salmoniformes). Chromosoma, 34, 436-447.

Collares-Pereira, M. (1992). In vivo direct chromosome preparation (protocol for air drying technique). Paper presented at the First International Workshop on Fish Cytogenetic Techniques. 14-24 September, Concarneau, France.

Crossman, E., \& Ráb, P. (2001). Chromosomal NOR phenotype and C-banded karyotype of Olympic Mudminnow, Novumbra hubbsi (Euteleostei: Umbridae). Copeia, 3, 860-865.

Davisson, M. T. (1972). Karyotypes of the teleost family Esocidae. Journal of the Fisheries Board of Canada, 29, 579-582.

Fricke, R., Bilecenoglu, M., \& Sarı, H. (2007). Annotated checklist of fish and lamprey species of Turkey, including a red list of threatened and declining species. Stuttgarter Beitr Naturkunde, Serie A (Biologie), 706, 1-169.

Gandolfi, A., Ferrari, C., Crestanello, B., Girardi, M., Lucentini, L., \& Meraner, A. (2017). Population genetics of pike, genus Esox (Actinopterygii, Esocidae), in Northern Italy: evidence for mosaic distribution of native, exotic and introgressed populations. Hydrobiologia, 794, 73-92.

Howell, W. M., \& Black, D. A. (1980). Controlled silver-staining of nucleolus organizer regions with a protective colloidal developer: a 1-step method. Experientia, 36(8), 1014-1015.

Jankun, M., Woznicki, P., Dajnowicz, G., Demska-Zakes, K., Luczynski, M. J., \& Luczynski, M. (1998). Heterochromatin and NOR location in northern pike (Esox lucius). Aquatic Sciences, 60, 17-21.

John, B., \& Miklos, G. L. G. (1979). Functional aspects of satellite DNA and heterochromatin. International Review of Cytology, 58, 1-114.

Levan, A., Fredga, K., \& Sandberg, A. A. (1964). Nomenclature for centromeric position on chromosomes. Hereditas, 52 (2), 201-220.

Liberman, E., Voropaeva, E., \& Kozlov, S. (2019). Parasitofauna of pike Esox lucius of the Lower Tobol (Russia). Biosystems Diversity, 27(3), 214-220.

McGregor, J. F. (1970). The chromosomes of the maskinonge (Esox masquinongy). Canadian Journal of Genetics and Cytology, 12(2), 224-229.

Nygren, A., Edlund, P., Hirsch, U., \& Åhsgren, L. (1968). Cytological studies in Perch (Perca fluviatilis L.), Pike (Esox lucius L.), Pike-Perch (Lucioperca lucioperca L.), and Ruff (Acerina cernua L.). Hereditas, 59(2-3), 518-524.

Ráb, P. (1981). Karyotype of European mudminnow, Umbra krameri. Copeia, 911-913.

Ráb, P., \& Crossman, E. (1994). Chromosomal NOR phenotypes in North American pikes and pickerels, genus Esox, with notes on the Umbridae (Euteleostei: Esocae). Canadian Journal of Zoology, 72, 1951-1956.

Ráb, P., \& Mayr, B. (1987). Chromosome banding studies in European esocoid fishes: localization of nucleolar organizer regions in Umbra krameri and Esox lucius. Copeia, 4, 1062-1067.

Sumner, A. (1972). A simple technique for demonstrating centromeric heterochromatin. Experimental Cell Research, 75, 304-306.

Sumner, A. (1982). The nature and mechanisms of chromosome banding. Cancer Genetics and Cytogenetics, 6 , 59-87.

Symonová, R., Ocalewicz, K., Kirtiklis, L., Delmastro, G. B., Pelikánová, Š., Garcia, S., \& Kovařík, A. (2017). Higher-order organisation of extremely amplified, potentially functional and massively methylated 5S rDNA in European pikes (Esox sp.). BMC genomics, 18, 391.

Zou, S. M., \& Li, S. F. (2006). The study on chromosomes of white spot pike (Esox lucius). Journal of Shanghai Fisheries University, 2, 203-211. 